\title{
Bio-sorption for effective removal of chromium(VI) from wastewater using Moringa stenopetala seed powder (MSSP) and banana peel powder (BPP)
}

\author{
Tolera Seda Badessa*, Esayas Wakuma and Ali Mohammed Yimer
}

\begin{abstract}
Chromium is an extremely toxic metal in the form of $\mathrm{Cr}(\mathrm{VI})$ that causes severe environmental and health problems. Therefore, the aim of this study was to remove chromium ions from wastewater by using cost effective and environmentally friendly bio-sorbents; Moringa stenopetala seed powder (MSSP), and banana peel powder (BPP) and to evaluate its adsorption capacities as bio-sorbents. FT-IR characterization of the adsorbents showed that there was a change in the functional groups of the structure of both adsorbents before and after the adsorption that might be due to the adsorption processes taken place on the surface of adsorbent. Adsorption experiments were carried out as batch studies with different contact times, $\mathrm{pH}$, adsorbent dose, initial metal ion concentration, and temperature. Results showed maximum removal efficiency for $\mathrm{Cr}(\mathrm{VI})$ at 120 min contact time, adsorbent dose of $20 \mathrm{~g} / \mathrm{L}$ and pH 2 by MSSP and $\mathrm{pH} 4$ by BPP. The percentage removal of $\mathrm{Cr}(\mathrm{VI})$ increased with increasing adsorbent dose (from 5 to $20 \mathrm{~g} / \mathrm{L}$ ) and contact time (from 60 to $120 \mathrm{~min}$ ). Freundlich isotherm model showed a better fit to the equilibrium data than the Langmuir model. The kinetics of adsorption for chromium was well represented by pseudo-second order kinetic model and the calculated equilibrium sorption capacity of the model showed good agreement with the sorption capacity obtained from experimental results.
\end{abstract}

Keywords: Moringa stenopetala, Banana peel, Chromium(VI), FT-IR, Adsorption isotherms

\section{Introduction}

Chromium is a naturally occurring metal found in the environment commonly in trivalent, $\mathrm{Cr}$ (III), and hexavalent, $\mathrm{Cr}(\mathrm{VI})$ forms $[1,2]$. The trivalent state of chromium [Cr(III)] is essential for carbohydrate metabolism in humans, whereas hexavalent chromium $[\mathrm{Cr}(\mathrm{VI})]$ is considered to be toxic $[3,4]$. The hexavalent chromium is a 100 -fold more toxic than trivalent form of chromium $[5,6]$. This is due to the fact that it is a strong oxidizing agent that can release free radicals

*Correspondence: toleraseda@yahoo.com

Department of Chemistry, College of Natural Sciences, Arba Minch University, Arba Minch, Ethiopia that can have carcinogenic effects on cells [4]. Chromium containing compounds in the form of hexavalent is used widely in different industries such as leather industry, electroplating, textile dyeing, and metal fabrication and finishing [7]. Chromium containing wastewater is one of the major pollutants of the environment. Hence, industries must treat the effluents to reduce the Chromium ions concentration in water and wastewater to acceptable levels before releasing it into the natural environment. Various conventional and advanced treatment methods have been employed for the removal of $\mathrm{Cr}$ ions from water and wastewater in developed countries. These include chemical precipitation, ion exchange, reverse osmosis, membrane 
filtration, electrodialysis, polymeric nano particles and activated carbon adsorptions [8-13]. However, these conventional and advanced technologies are expensive and non-regenerable materials used, generation of toxic sludge is often ineffective, particularly for the removal of $\mathrm{Cr}$ ions at low concentrations and also difficult to apply them in developing countries like Ethiopia [14-16].

Moringa is a tropical plant belonging to the family of moringaceae that grows throughout the tropical regions. Moringa oleifera and Moringa stenopetala are the two most common species among the various species of the moringa family $[17,18]$. Moringa stenopetala is domesticated in the east African low lands and is indigenous to southern Ethiopia. Moringa stenopetala is often called "cabbage tree" and is an important indigenous vegetable in south Ethiopia where it is cultivated as a food crop $[19,20]$. The water soluble moringa seed possess coagulating properties similar to those of synthetic cationic polymers. Moringa seeds contain cationic polypeptides with various functional groups, particularly low molecular weight amino acids. These amino acids are de-protonated to carboxylate ligands at $\mathrm{pH}$ range of 4 to 8 simultaneously protonating the amino group which facilitates the binding of positively charged ions with the carboxylic group [21, 22]. The use of bio-adsorbents like Moringa stenopetala seed powder that are easily available and effective for removal of metals could be an innovative and economical approach for treatment of industrial wastewater.

Banana is another plant most widely grown in tropical regions, cultivated over 130 countries. Ethiopia, which lies entirely in the tropics, has great potential for banana production [23]. Cavendish banana is the major fruit crop that widely grown and consumed in Ethiopia especially in the south and south western part of the country [24]. Banana is rich in polyphenols, flavonoids and dopamine which exist both in the pulp and the peel [25]. The pectin substances are complex hetero polysaccharides containing galacturonic acid, arabinose, galactose, and rhamnose as the major sugar constituents; the carboxyl groups of galacturonic acid allow pectin substances to strongly bind metal cations in aqueous solution [26]. Thus, banana peels powder could be used for the bio-adsorption of metal ions in wastewaters. The needs for cost-effective, eco-friendly and locally available alternative materials for the removal of chromium ion from aqueous solutions is essential. Therefore, Moringa stenopetala seed powder and banana peel powder for their adsorptive removal of $\mathrm{Cr}(\mathrm{VI})$ ions from aqueous solutions under various operating variables (contact time, solution $\mathrm{pH}$, initial $\mathrm{Cr}$ concentration and temperature) was the focus of the current work.

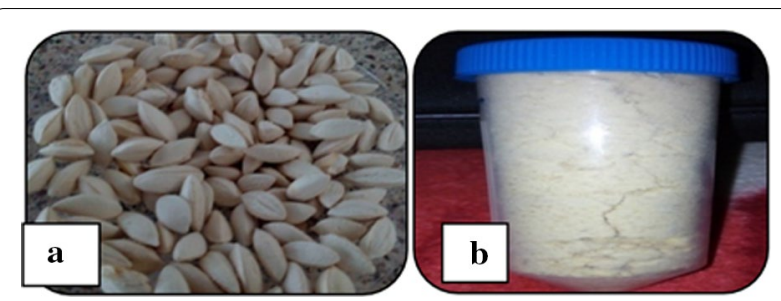

Fig. 1 Moringa stenopetala sample, a seed and b seed powder

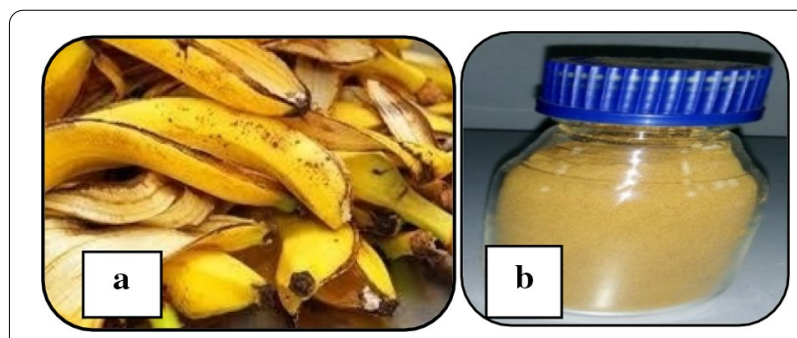

Fig. 2 Banana peel sample a raw peel, $\mathbf{b}$ peel powder

\section{Materials and methods}

Preparation of Moringa stenopetala seed powders (MSSP)

Matured and fresh seeds of Moringa stenopetala were collected from Arba Minch University and specimen identification of the seed was done at Addis Ababa University National Herbarium. Then the seeds were separated from their cover or shell manually. They were, air-dried and ground using a grinding mill and sieved through a mesh. Finally, the fine powder of the seed shown in Fig. 1b, was collected and kept in a clean bottle until experiments were done.

\section{Preparation of banana peel powders (BPP)}

The banana fruits were collected from the local market of Arba Minch City, and the peel shown in Fig. 2 was separated from the fruits and cut into smaller pieces while washing thoroughly with tap and distilled water to remove dirt particles. Finally, the wetted banana peel was air-dried, ground into a powder, and kept in a clean airtight bottle; until experiments were done.

\section{Preparation of adsorbate}

A $1000 \mathrm{mg} / \mathrm{L}$ of $\mathrm{Cr}(\mathrm{VI})$ stock solution was prepared (2.827 $\mathrm{g}$ of $\mathrm{K}_{2} \mathrm{Cr}_{2} \mathrm{O}_{7}$ in $1000 \mathrm{~mL}$ volumetric flask using distilled-deionized water) [27]. Then a series of working standard solutions of different concentrations were prepared by appropriate dilution of the stock solution. 


\section{Batch experiments}

All experiments were carried out in batch mode to obtain both the thermodynamic and kinetic information. The studies were carried out at the optimized contact time, $\mathrm{pH}$ value, and adsorbent dosage. Before adding the adsorbent, the $\mathrm{pH}$ of the solution was adjusted by using $0.1 \mathrm{M} \mathrm{NaOH}$ or $0.1 \mathrm{M} \mathrm{HCl}$ solutions. To ensure equal mixing of the solution, all the experiments were performed with an orbital shaker with a constant agitation speed of $150 \mathrm{rpm}$. The equilibrium study was conducted and compared with Langmuir and Freundlich isotherm models. The kinetics experiments were studied using pseudo-first-order and pseudo-second-order models. After completing the batch experiment, the solution was separated from the adsorbent and digested in a microwave digester for the determination of its concentration using GFAAS. The blank solutions that contain the adsorbents before adsorption were also digested in the same way that the samples were done, and analysed for the chromium content The method detection limit was developed from the results to control the interferences coming from the adsorbent nature. Therefore, the result of adsorbed chromium was reported based on the method detection limit. Then, the adsorption efficiency (\%) and capacity at a given contact time for the selected adsorbents were determined using Eqs. 1 and 2 [28, 29].

$$
\begin{aligned}
& \text { \%Removal }=\frac{\left(C_{0}-C f\right)}{C_{0}} \times 100, \\
& \mathrm{q}=\frac{\left(C_{0}-C_{f}\right) \mathrm{V}}{m},
\end{aligned}
$$

where $C_{0}$ is the initial concentration, $C f$ is the concentration after adsorption, $\mathrm{q}$ is the metal removal in $\mathrm{mg} / \mathrm{g}$, $\mathrm{m}$ is the adsorbent mass in gram and $\mathrm{V}$ is the volume of wastewater used during the experiment.

\section{Adsorption isotherm}

The adsorption isotherm is a graphical representation of expressing the amount of solute adsorbed per unit mass of adsorbent as a function of equilibrium concentration in bulk solution at constant temperature. The experiments were carried out under different adsorbent dose that ranged from 0.5 to $2 \mathrm{~g}$ with an interval of $0.5 \mathrm{~g}$ by keeping the previously determined parameters at the optimal level in $100 \mathrm{~mL}$ solution of the metal ion with an agitation speed of $150 \mathrm{rpm}$. Then, the experiments were designed and conducted for the evaluation of adsorption equilibria between the adsorbate and adsorbent and finally compared with the existing models. The results were found to be fitting both the Langmuir and Freundlich adsorption isotherm models [30-33].

The Langmuir model assumes that uptake of adsorbate molecule occurs on a homogenous surface by monolayer adsorption without any interaction between adsorbed molecules and uniform energies of adsorption [34]. The Langmuir equation is represented as:

$$
q_{e}=\frac{\left(q_{m} \mathrm{~b} C_{e}\right)}{\left(1+\mathrm{b} C_{e}\right)}
$$

where $C_{e}$ is the equilibrium concentration of the ion $(\mathrm{mg} / \mathrm{L}) ; \mathrm{q}_{\mathrm{e}}$ is the amount of ion adsorbed $(\mathrm{mg} / \mathrm{g}) ; \mathrm{q}_{\mathrm{m}}$ is $\mathrm{q}_{\mathrm{e}}$ for a complete monolayer $(\mathrm{mg} / \mathrm{g})$; and $\mathrm{b}$ is the bio-sorption equilibrium constant $(\mathrm{L} / \mathrm{mg})$.

The linear form of Langmuir isotherm model can be represented by using Eq. 4:

$$
\frac{c_{e}}{q_{e}}=\left(\frac{1}{q_{m} \mathrm{~b}}\right)+\left(\frac{c_{e}}{q_{m}}\right) .
$$

The essential characteristics of the Langmuir isotherm can be explained by the equilibrium separation factor $\mathrm{R}_{\mathrm{L}}$, defined as:

$$
R_{L}=\frac{1}{\left(1+\mathrm{b} C_{o}\right)},
$$

where $b$ is the Langmuir constant and $C_{o}$ is the highest metal concentration $(\mathrm{mg} / \mathrm{L})$.

Depending on the value of $R_{L}$, the shape of the isotherm and whether the bio-sorption is favourable or not, can be determined. The types of isotherms with $R_{L}$ values are given in [35-37].

Freundlich isotherm model describes a multi-layer biosorption based on adsorption on heterogeneous surface and adsorption capacity which is related to the concentration of the adsorbent. The model can be presented as [38].

$$
q_{e}=K_{f} C_{e}^{1 / \mathrm{n}},
$$

where $\mathrm{q}_{\mathrm{e}}$ is the amount of ion adsorbed $(\mathrm{mg} / \mathrm{g}) ; \mathrm{C}_{\mathrm{e}}$ is the equilibrium concentration $(\mathrm{mg} / \mathrm{L}) ; \mathrm{K}_{\mathrm{f}}$ and $1 / \mathrm{n}$ are empirical constants, indicating the adsorption capacity (Freundlich constant) and adsorption intensity (which varies with the heterogeneity of the material), respectively.

The two Freundlich parameters $K_{f}$ and $1 / n$ can be determined graphically by plotting the experimental data and then using the Freundlich equation in the following form.

$$
\ln q_{e}=\ln K_{f}+\frac{1}{n} \ln C_{e},
$$


where $\mathrm{K}_{\mathrm{f}}$ and $1 / \mathrm{n}$ are evaluated from the intercept and slope of the plot of $\operatorname{lnq}_{\mathrm{e}} \mathrm{vs} . \ln _{\mathrm{e}}$. For values in the range $0.1<1 / \mathrm{n}<1$, bio-sorption is favourable. The greater the values of $\mathrm{K}_{\mathrm{f}}$, better is the favourability of bio-sorption.

\section{Adsorption kinetics}

The effect of time on the removal rate of $\mathrm{Cr}(\mathrm{VI})$ ion from the solution were investigated using kinetic study. Adsorption kinetics shows a large dependence on the physical and/or chemical characteristics of the adsorbent material. The experiment was conducted in a separate $250 \mathrm{~mL}$ Erlenmeyer flask by keeping $\mathrm{pH}$, adsorbent dose and metal ion concentration at the optimum level in different time intervals (30 min, $60 \mathrm{~min}, 90 \mathrm{~min}, 120 \mathrm{~min}$ and $150 \mathrm{~min}$ ) by adjusting the agitation speed at $150 \mathrm{rpm}$. Finally, the experimental data were analyzed using pseudo first-order [32] and pseudo-second order [33] kinetics models.

Pseudo-first order kinetics model was based on adsorption capacity of adsorbent and suggests that there are no interactions between ions and each ion sorbs on a local site. Therefore, the designed experiment for the bio-sorption process was undergone the pseudo-first order kinetics as the adsorption is occurring as monolayer on the surface of adsorbent and the equation is expressed as [32]:

$$
\frac{d q_{t}}{d t}=\mathrm{k}_{1}\left(q_{e}-q_{t}\right)
$$

where $\mathrm{q}_{\mathrm{e}}$ and $\mathrm{q}_{\mathrm{t}}$ are the amounts ( $\mathrm{mg} / \mathrm{g}$ ) of adsorbed pollutant on the adsorbent at equilibrium and time t; and $k_{1}$ is the rate constant $\left(\mathrm{min}^{-1}\right)$ of Lagergren's first-order adsorption.

After integration and applying boundary conditions $t=0$ to $\mathrm{t}=\mathrm{t}$ and $\mathrm{q}_{\mathrm{t}}=0$ to $\mathrm{q}_{\mathrm{t}}=\mathrm{q}_{\mathrm{e}}$, the integrated form becomes:

$$
\log \left(q_{e}-q_{t}\right)=\log q_{e}-\frac{k 1 t}{2.303} \text {. }
$$

The plot of $\log \left(\mathrm{q}_{\mathrm{e}}-\mathrm{q}_{\mathrm{t}}\right)$ versus $\mathrm{t}$ gives a straight line for first-order adsorption kinetics which allows the computation of the rate constant $k_{1}$ and $\mathrm{q}_{\mathrm{e}}$ from the slop and intercept of the plot.

The pseudo-second-order kinetics model is based on the assumption that the bio-sorption follows a second order mechanism and the occupation rate of the adsorption site is proportional to the square of the number of unoccupied sites. The rate equation can be represented in the following form [33].

$$
\frac{d q_{t}}{d t}=k_{2}\left(q_{e}-q_{t}\right)^{2}
$$

where $\mathrm{k}_{2}$ is the rate constant $(\mathrm{g} / \mathrm{mg} \mathrm{min})$ of second-order adsorption.

The integrated form of the Eq. (10) becomes:

$$
\frac{1}{q_{e}-q_{t}}=\frac{1}{q_{e}}+k_{2} t
$$

The linear form of Eq. (11) is as follows:

$$
\frac{t}{q_{t}}=\frac{1}{k_{2} q_{e} 2}+\frac{1}{\left(q_{e}\right) t} \text {. }
$$

The $\mathrm{k}_{2}$ and $\mathrm{q}_{\mathrm{e}}$ values of the pseudo-second-order kinetic model can be determined from the intercept and slope of the plots of $t / q_{t}$ versus $t$.

\section{Thermodynamic study}

Thermodynamic parameters provide in-depth information of inherent energetic changes that are associated with adsorption. The thermodynamic parameters such as standard Gibbs free energy change $\Delta G^{\circ}$, standard enthalpy change $\Delta \mathrm{H}^{\circ}$, and standard entropy change $\Delta \mathrm{S}^{\circ}$ gives a better understanding of the effect of temperature on adsorption. These parameters were determined using the following equations [39].

$$
\begin{aligned}
& \Delta G^{\circ}=-R T \ln K_{c}, \\
& K_{c}=\frac{C_{a}}{C_{e}} .
\end{aligned}
$$

The Gibbs free energy change $\left(\Delta G^{\circ}\right)$ is related to the entropy change $\left(\Delta \mathrm{S}^{\circ}\right)$ and enthalpy change $\left(\Delta \mathrm{H}^{\circ}\right)$ at constant temperature using Eq. 15:

$$
\Delta G^{\circ}=\Delta H^{\circ}-\mathrm{T} \Delta S^{\circ} .
$$

By combining the above two equations we get the following equation:

$$
\ln \mathrm{K}_{\mathrm{c}}=\frac{\Delta S^{\circ}}{R}-\frac{\Delta H}{R T},
$$

where $K_{c}$ is the equilibrium constant, $T$ is the absolute temperature $(\mathrm{K}), \mathrm{R}$ is the universal gas constant $\left(8.314 \mathrm{~J} \mathrm{~mol}^{-1} \mathrm{~K}^{-1}\right), C_{a}(\mathrm{mg} / \mathrm{L})$ is the amount of metal ion adsorbed at equilibrium, $C_{e}(\mathrm{mg} / \mathrm{g})$ is the amount of metal ion left in the solution at equilibrium. The values of $\Delta \mathrm{H}^{\circ}$ and $\Delta \mathrm{S}^{\circ}$ were calculated from the slope and intercept of the Van't Hoff plot of $\ln K_{c}$ versus $1 / T$ equation [27].

\section{Results and discussion}

\section{FT-IR result for BPP and MSSP}

The FT-IR spectra before and after adsorption of chromium were given for both BPP and MSSP in which the absorption peaks appeared in the wavenumber range of $3500 \mathrm{~cm}^{-1}$ to $625 \mathrm{~cm}^{-1}$. The Fig. 3a shows the absorbance spectra of BPP and MSSP before adsorption and Fig. $3 \mathrm{~b}$ indicates the absorbance spectra of BPP and MSSP after adsorption of chromium taken place. The 

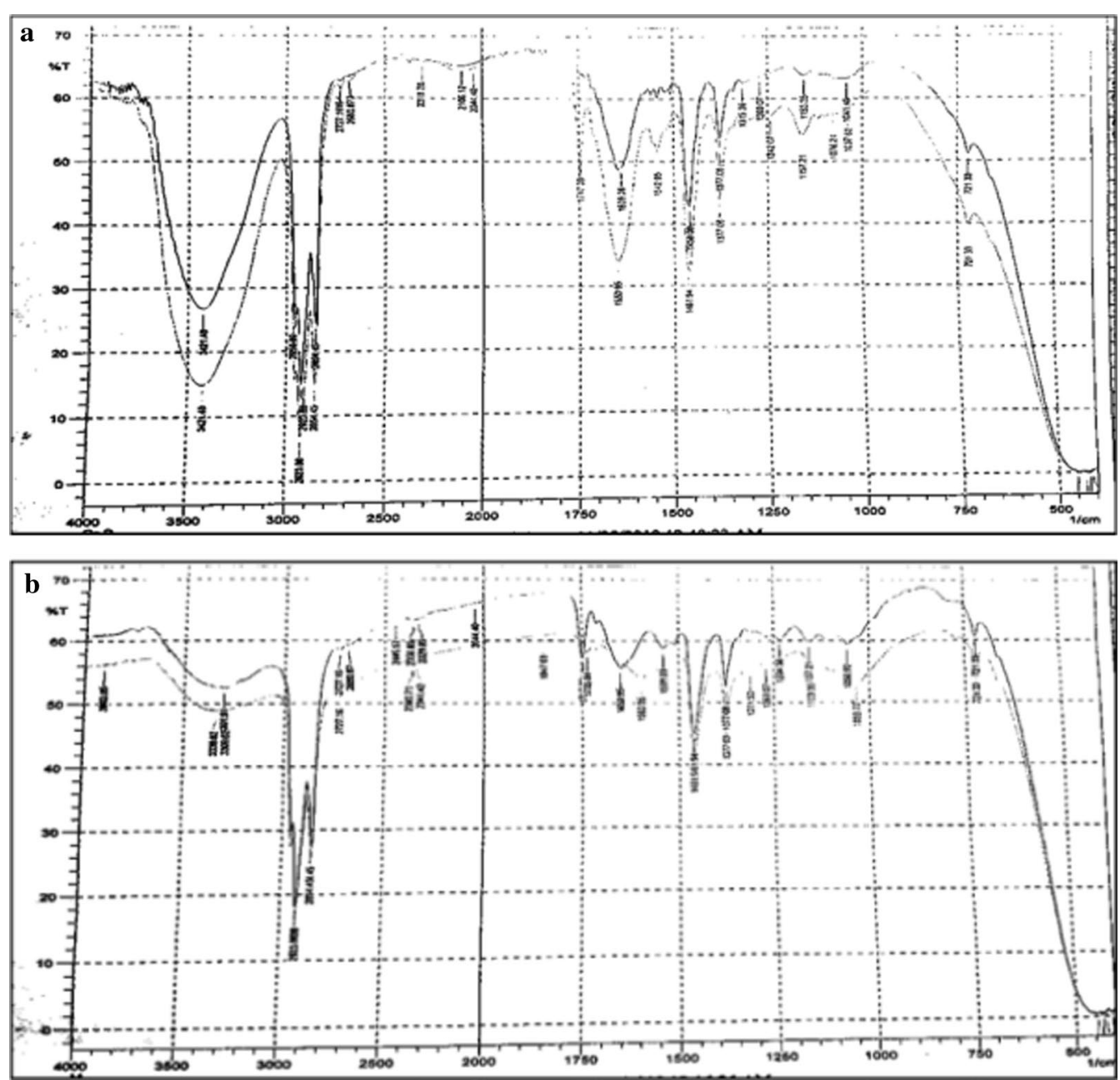

Fig. 3 FT-IR spectra of $\mathbf{a}$ BPP and MSSP before adsorption, $\mathbf{b}$ BPP and MSSP after adsorption

spectra containing weak bands in both figures represent the absorbance spectra of BPP before and after adsorption where as the one containing stronger bands in both figures are indicating the absorbance spectra of MSSP before and after adsorption.

The FT-IR spectra in Fig. 3a shows that broad bands at $3337 \mathrm{~cm}^{-1}$ and $3310 \mathrm{~cm}^{-1}$ indicate that $\mathrm{O}-\mathrm{H}$ stretching vibration of carboxylic acid for both BPP and MSSP. These bands disappeared (decreased highly in intensity) in Fig. 3b, which confirms that the adsorption of chromium by both adsorbents was highly effective. In the same way a band at $1654 \mathrm{~cm}^{-1}$ in both figures indicate that stretching vibration of $\mathrm{C}=\mathrm{O}$ group in carboxylic acid. In Fig. $3 \mathrm{~b}$ these bands for both BPP and MSSP were also decreased in intensity that confirms adsorption of chromium on both adsorbents.

\section{Effect of contact time}

The percentage removal of $\mathrm{Cr}(\mathrm{VI})$ ions and the adsorption capacity of MSSP and BPP as a function of contact time was conducted at $60,90,120$ and 150 min using different $\mathrm{pH}$ and dose at a constant initial concentration, agitation speed and temperature. The experimental results shown in Fig. 4 indicate that the percentage removal of $\mathrm{Cr}(\mathrm{VI})$ ion increases with increasing contact time up to $120 \mathrm{~min}$. Further increase in contact time did not make any change in removal and adsorption capacity. Higher removal efficiency and adsorption 

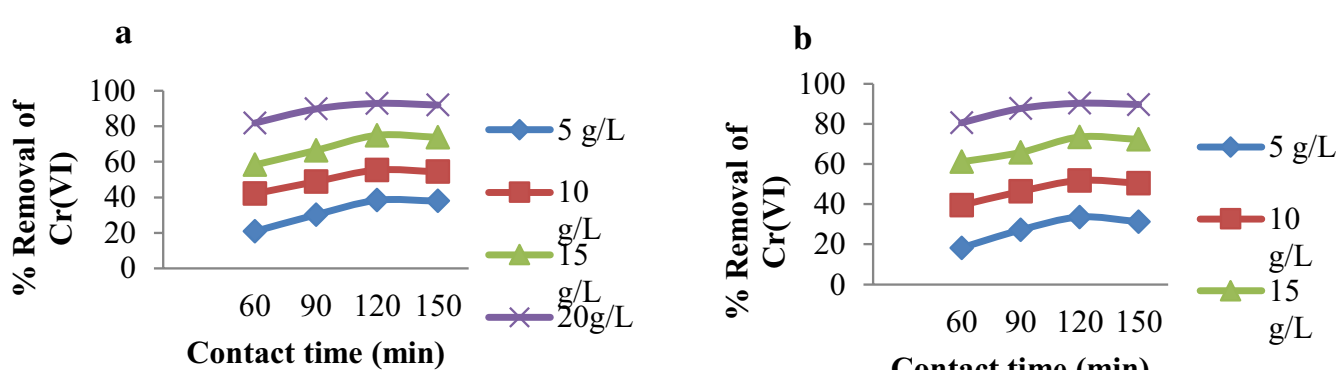

Contact time (min)

Fig. 4 Effect of contact time on \% removal of: A/Cr(VI) by MSSP and B/Cr(VI) by BPP (concentration $30 \mathrm{mg} / \mathrm{L}$, contact time 60, 90, 120 and 150 min, adsorbent dose 5, 10, 15 and $20 \mathrm{~g} / \mathrm{L}$ solution, agitation speed $150 \mathrm{rpm}$ and $\mathrm{pH}=2$ for $\mathrm{MSSP}, \mathrm{pH}=4$ for BPP)

capacity was observed at $120 \mathrm{~min}$ for both the adsorbents. Hence, $120 \mathrm{~min}$ was chosen as the equilibrium time. Because at the beginning of the process, adsorption is fast due to the availability of large active binding site but as time has gone, the process slow down as active binding sites are filled by the metal ion.

\section{Effect of $\mathrm{pH}$}

Solution $\mathrm{pH}$ is one of the most important parameters while assessing the adsorption capacity of an adsorbent for metal ion sequestration from aqueous. The $\mathrm{pH}$ of the system controls the adsorption capacity due to its influence on the surface properties of the adsorbent and ionic forms of the chromium solutions.

$\mathrm{Cr}(\mathrm{VI})$ adsorption was studied as a function of $\mathrm{pH}$ over a range of 2-8 for MSSP and BPP at an initial concentration of $30 \mathrm{mg} / \mathrm{L}$ wastewater. The results of the experiment shown in Fig. 3 indicate that optimal $\mathrm{Cr}(\mathrm{VI})$ removal efficiency of MSSP and BPP were obtained at $\mathrm{pH} 2.0$ and pH4.0 respectively for 120 min contact time. It is evident that chromium(VI) removal efficiency increases with decrease in $\mathrm{pH}$ [31]. The favorable effect at low $\mathrm{pH}$ might be due to the neutralization of negative changes on the surface of the adsorbents by excess hydrogen ions, thereby facilitating the diffusion of the hydrogen chromate ion $\left(\mathrm{HCrO}_{4}^{-}\right)$and its subsequent adsorption, because $\mathrm{HCrO}_{4}{ }^{-}$is the dominant anionic form of $\mathrm{Cr}(\mathrm{VI})$ between $\mathrm{pH} 1.0$ and 4.0. This ionic form was found to be preferentially adsorbed on the surface of the adsorbent. The possible explanation for higher adsorption in the acidic region is that the $\mathrm{Cr}_{2} \mathrm{O}_{7}{ }^{2-}$ ion is oxidized to $\mathrm{Cr}_{3}{ }^{+}$. Being small in size, it can be easily replaced by the positively charged species The following reaction mechanism might be taken place during adsorption processes on the surface of adsorbents [40, 41].

$$
\begin{aligned}
& 2 \mathrm{H}^{+}+2 \mathrm{HCrO}_{4}^{-} \leftrightarrow 2 \mathrm{H}_{2} \mathrm{CrO}_{4} \leftrightarrow 2 \mathrm{H}_{2} \mathrm{O}+\mathrm{Cr}_{2} \mathrm{O}_{7}^{2-}+2 \mathrm{H}^{+} \\
& 2 \mathrm{H}_{2} \mathrm{O}+\mathrm{Cr}_{2} \mathrm{O}_{7}^{2-}+2 \mathrm{H}^{+} \leftrightarrow 2 \mathrm{H}_{2} \mathrm{Cr}_{4} \leftrightarrow 2 \mathrm{CrO}_{3}+2 \mathrm{H}_{2} \mathrm{O}
\end{aligned}
$$

Therefore, chromium removal in $\mathrm{mg} / \mathrm{g}$ by MSSP and BPP increases with increasing contact time from 60 to $120 \mathrm{~min}$. for all $\mathrm{pH}$ values; this is because the solution $\mathrm{pH}$ is directly related to the large availability of positively charged active sites on the surface of the adsorbent to bind with the metal ions as the solution $\mathrm{pH}$ decreases, the surface of the adsorbents exhibits increasing positively charged active sites. As $\mathrm{pH}$ decreases, the removal efficiency becomes increasing that was shown in Fig. 5. The maximum adsorption of $\mathrm{Cr}(\mathrm{VI})$ was observed at the acidic range because, at

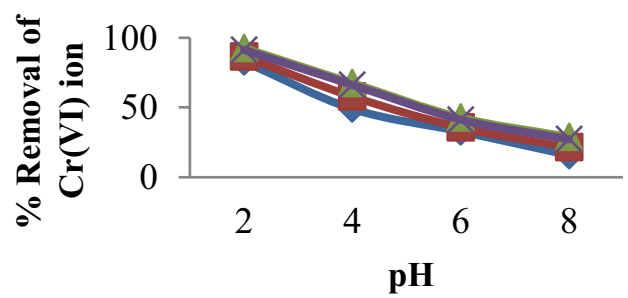

b

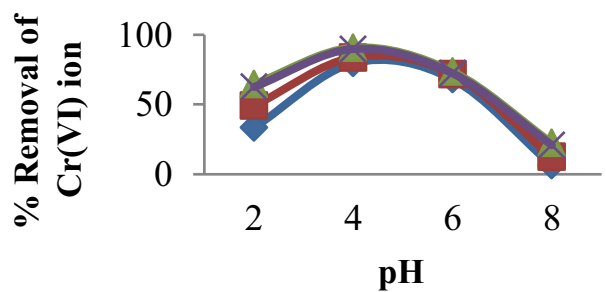

Fig. 5 Effect of solution pH on \% removal of: a $\mathrm{Cr}(\mathrm{VI})$ by MSSP and $\mathbf{b} \mathrm{Cr}(\mathrm{VI})$ by BPP (concentration $30 \mathrm{mg} / \mathrm{L}, \mathrm{pH}, 2,4,6$ and 8 and contact time 60, 90, 120 and $150 \mathrm{~min}$, agitation speed $150 \mathrm{rpm}$ ) 
lower $\mathrm{pH}$, there is an increase in $\mathrm{H}^{+}$ions on the adsorbent surface, and the presence of $\mathrm{HCrO}_{4}{ }^{-}$ions result in significantly strong electrostatic attraction [42].

\section{Effect of adsorbent dose}

The effect of the adsorbent dose on the removal of $\mathrm{Cr}(\mathrm{VI})$ ions onto MSSP and BPP was conducted by using 5 , 10,15 and $20 \mathrm{~g} / \mathrm{L}$ of adsorbent dose under variable $\mathrm{pH}$ and contact time on keeping agitation speed and initial concentration constant. Figure 6 shows that the percent removal of chromium by MSSP increases from 24.85 to $90.96 \%$ and by using BPP it ranges from 20.06 to $89.62 \%$ with an increase in adsorbent dose from 5 to $20 \mathrm{~g} / \mathrm{L}$ at all $\mathrm{pH}$ values. The increase in adsorbent dose generally increases the percent removal of the metal ion due to increased surface area of the adsorbent which increases the number of available binding sites for the adsorption process. On the other hand, the quantity of adsorbate metal ion per unit weight of the adsorbent decreases with increasing in the adsorbent dose and this may be due to high adsorbent concentration. If the available metal ion to be sorbed is not sufficient to completely cover the available active sites of the adsorbents, it is leading to the reduction of metal ion uptake [43].

On the other hand, adsorption capacity in $\mathrm{mg} / \mathrm{g}$ decreases with increasing adsorbent dose for all $\mathrm{pH}$ values. The highest removal efficiency was observed at $5 \mathrm{~g} / \mathrm{L}$ of adsorbent. Adsorbent dose has also its own effect on the removal efficiency at various contact time. Higher adsorption was obtained at $20 \mathrm{~g} / \mathrm{L}$ for all contact times but at this dose percent removal variations among different contact times were small. This may be explained by the presence of screening effect when the adsorbent dose increases [44]. Thus, the removal efficiencies of chromium ions at optimal adsorbent concentration were selected as $20 \mathrm{~g} / \mathrm{L}$ [45].

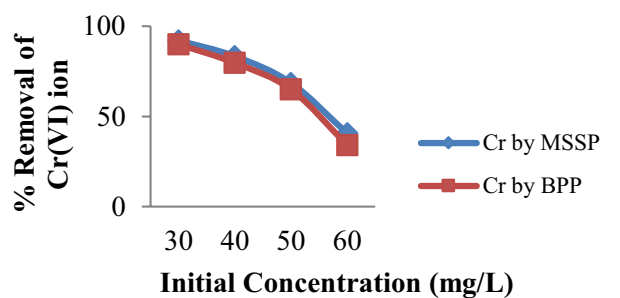

Fig. 7 Effect of initial concentration on \% removal of $\mathrm{Cr}(\mathrm{VI})$ by MSSP and by BPP [dose $20 \mathrm{~g} / \mathrm{L}$, contact time $120 \mathrm{~min}$ and $\mathrm{pH} 2$ for $\mathrm{Cr}(\mathrm{VI})$ by MSSP and $\mathrm{pH} 4$ for $\mathrm{Cr}(\mathrm{VI})$ by BPP]

\section{Effect of initial concentration of chromium}

The experiment was carried out under optimal conditions and different initial concentration ranging from $30 \mathrm{mg} / \mathrm{L}$ up to $60 \mathrm{mg} / \mathrm{L}$ with an interval of $10 \mathrm{mg} / \mathrm{L}$. As shown in Fig. 7, the increasing of the initial concentration of chromium increases adsorption capacity of the adsorbents but decreases percentage removal of the metal. Maximum \% removal of chromium by MSSP is $92.17 \%$ and by BPP is 90.07 at $30 \mathrm{mg} / \mathrm{L}$. The decrease in percentage removal of the metal ion with increasing initial concentration may be due to the saturation of adsorption sites on the adsorbent surface. This can be explained by the fact that, at low concentration, the metal ions interact with the binding sites and result in maximum adsorption. This is because, at low concentration, the ratio of available surface to the initial metal ion concentration is larger, so the removal is higher [46]. On the other hand, maximum $\mathrm{Cr}(\mathrm{VI})$ ion adsorption capacity of MSSP is $1.71 \mathrm{mg} / \mathrm{g}$ and that of BPP is $1.63 \mathrm{mg} / \mathrm{g}$ at initial concentration of $50 \mathrm{mg} / \mathrm{L}$. The increase in adsorption capacity with increasing initial concentration is due to the fact that, at fixed adsorbent dose with increasing the metal concentration, all the available active sites of the adsorbent would be fully exposed to get occupied by the metal ions that are in excess saturating and yielding a higher adsorption capacity [47].
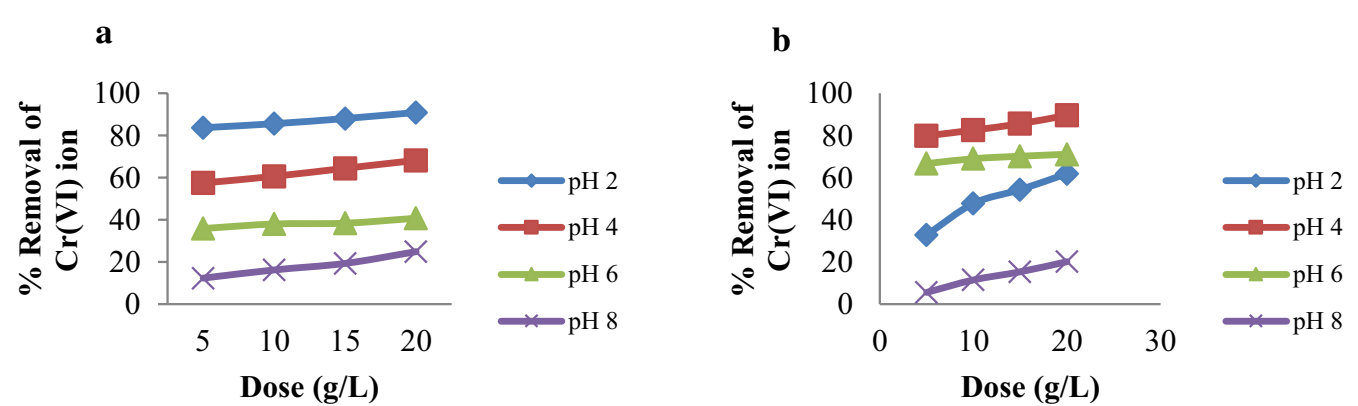

Fig. 6 Effect of adsorbent dose on \% removal of: a $\mathrm{Cr}(\mathrm{VI})$ by MSSP and $\mathbf{b} \mathrm{Cr}(\mathrm{VI})$ by BPP (concentration $30 \mathrm{mg} / \mathrm{L}$, agitation speed rpm, adsorbent dose 5, 10, 15 and $20 \mathrm{~g} / \mathrm{L}$ solution, $\mathrm{pH}$ 2, 4, 6 and 8) 


\section{Effect of temperature}

The effect of temperature on adsorption capacity of $\mathrm{Cr}(\mathrm{VI})$ onto MSSP and BPP was studied at a temperatures of $293 \mathrm{k}, 313 \mathrm{k}, 333 \mathrm{k}$ and $353 \mathrm{k}$ at the optimal conditions of the solution. As shown in Fig. 8, an increase in temperature from 293 to $353 \mathrm{k}$ decreases the percentage removal from 91.40 to $37.93 \%$ that contains MSSP and from 90.03 to $33.80 \%$ for chromium solution that contains BPP respectively. Similar to percent removal, adsorption capacities of MSSP and BPP on the adsorption of $\mathrm{Cr}(\mathrm{VI})$ ion decreased from 1.37 to $0.57 \mathrm{mg} / \mathrm{g}$ and $1.35 \mathrm{mg} / \mathrm{g}$ to $0.51 \mathrm{mg} / \mathrm{g}$ with increasing temperature from 293 to $353 \mathrm{k}$. This fall of metal uptake capacity of the adsorbents during the rise in temperature might be due to desorption caused by an increase in the available thermal energy. Higher temperature induces higher mobility of the adsorbate causing desorption or the damage of active binding sites in the biomass [48]. The decrease in adsorption capacity with increasing temperature indicates that adsorption process is exothermic in nature.

\section{Adsorption isotherm}

The Langmuir plot between $1 / \mathrm{q}_{\mathrm{e}}$ vs. $1 / \mathrm{C}_{\mathrm{e}}$ for the sorption of $\mathrm{Cr}(\mathrm{VI})$ ion by MSSP and BPP are drawn in Fig. 9. It was found that the values of maximum adsorption capacity of MSSP and BPP were $9.709 \mathrm{mg} / \mathrm{g}$ and $7.353 \mathrm{mg} / \mathrm{g}$, respectively (Table 1). The essential characteristics of the Langmuir isotherm can be explained by the equilibrium separation factor $R_{L}$. The $R_{L}$ values for sorption of $\mathrm{Cr}(\mathrm{VI})$ ion by MSSP and BPP in this study were 0.325 and 0.275 , respectively. This indicates that MSSP and BPP are favourable adsorbents for the removal of chromium.

The Freundlich adsorption model is based on adsorption on heterogeneous surface and adsorption capacity related to the concentration of the adsorbent. The value of Freundlich constant $1 / \mathrm{n}$ and $\mathrm{K}_{\mathrm{f}}$ for the sorption of $\mathrm{Cr}(\mathrm{VI})$ by MSSP and BPP were obtained from a

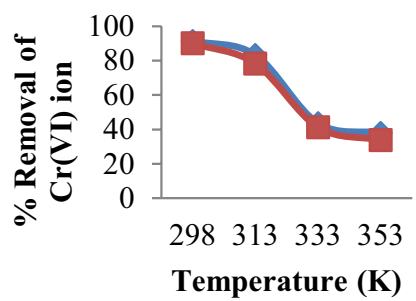

b

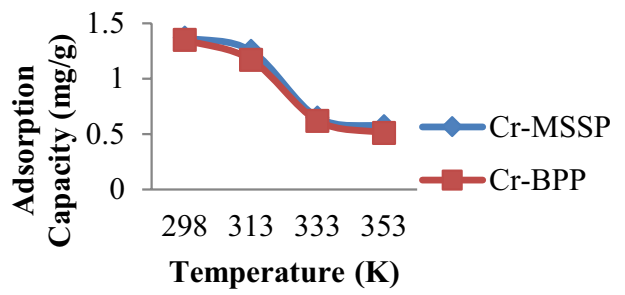

Fig. 8 Effect of temperature on: a \% removal of $\mathrm{Cr}(\mathrm{VI})$ and $\mathbf{b}$ adsorption capacity of MSSP [concentration $30 \mathrm{mg} / \mathrm{L}$, dose $20 \mathrm{~g} / \mathrm{L}$, contact time 120 min. and $\mathrm{pH} 2$ for $\mathrm{Cr}(\mathrm{VI})$ by MSSP and $\mathrm{pH} 4$ for $\mathrm{Cr}(\mathrm{VI})$ by BPP]

a

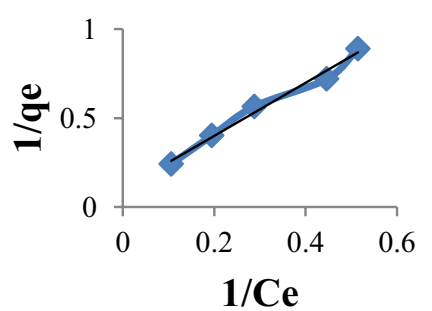

b

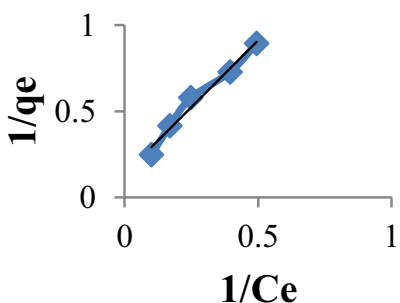

$\mathrm{y}=1.5492 \mathrm{x}+$ 0.1363

$\mathrm{R}^{2}=0.9764$<smiles>C1CC1[Al]1CC1</smiles>

Fig. 9 Langmuir adsorption isotherms for: $\mathbf{a}$ chromium by MSSP and $\mathbf{b}$ chromium by BPP

Table 1 Parameters of Langmuir and Freundlich adsorption isotherms of chromium

\begin{tabular}{|c|c|c|c|c|c|c|c|}
\hline \multirow[t]{2}{*}{ Metal ion } & \multicolumn{4}{|c|}{ Langmuir isotherm } & \multicolumn{3}{|c|}{ Freundlich isotherm } \\
\hline & $q_{m}$ & b & $\mathbf{R}_{\mathrm{L}}$ & $\mathrm{R}^{2}$ & $\overline{K_{f}}$ & $1 / n$ & $\mathrm{R}^{2}$ \\
\hline $\mathrm{Cr}(\mathrm{VI})-\mathrm{MSSP}$ & 9.709 & 0.0692 & 0.325 & 0.983 & 0.685 & 0.792 & 0.993 \\
\hline $\mathrm{Cr}(\mathrm{VI})-\mathrm{BPP}$ & 7.353 & 0.0879 & 0.275 & 0.976 & 0.635 & 0.779 & 0.983 \\
\hline
\end{tabular}


the slope and intercept of the plot $\log q_{e}$ vs. $\log C_{e}$. $K_{f}$ which is an indicator of adsorption capacity of adsorbent and the higher the adsorption capacity, the higher the value of $\mathrm{K}_{\mathrm{f}}$. On the other hand, $1 / \mathrm{n}$ is a measure of intensity of adsorption. Therefore, the $\mathrm{K}_{\mathrm{f}}$ value for the sorption of $\mathrm{Cr}(\mathrm{VI})$ ion by MSSP and BPP are 0.685 and 0.635 whereas the $1 / \mathrm{n}$ values for the sorption of $\mathrm{Cr}(\mathrm{VI})$ are 0.792 and 0.779 respectively. This indicates that both MSSP and BPP have high chromium sorption capacity and are favourable adsorbents from wastewater. The values of correlation coefficients $\left(R^{2}\right)$ of the Freundlich model given in Fig. 10, which were 0.993 and 0.983 for MSSP and BPP respectively and these values are larger than the $\mathrm{R}^{2}$ values of the Langmuir model $(0.983$ and 0.976). This indicates the Freundlich model fits better to the adsorption data and thus it is more suitable to be used to describe the relationship between the amounts of $\mathrm{Cr}(\mathrm{IV})$ ion adsorbed by MSSP and BPP.

\section{Adsorption kinetics}

From the experimental data shown in Table 2, the calculated and experimental equilibrium adsorption capacity, $\mathrm{q}_{\mathrm{e}}(\mathrm{cal})$ and $\mathrm{q}_{\mathrm{e}}(\mathrm{exp})$, of pseudo-second-order kinetic model was close to each other than the pseudo-firstorder kinetic model. This indicates that the pseudo-second order kinetics is the best kinetic model that fits to the experimental data for sorption of $\mathrm{Cr}(\mathrm{VI})$ by MSSP and BPP. The correlation coefficients $\left(\mathrm{R}^{2}\right)$ of pseudosecond-order kinetic model of chromium by MSSP and BPP (0.998 and 0.994) are closer to unity compared to the pseudo-first-order kinetic model (0.939 and 0.897). This indicates pseudo-second-order kinetic model is better
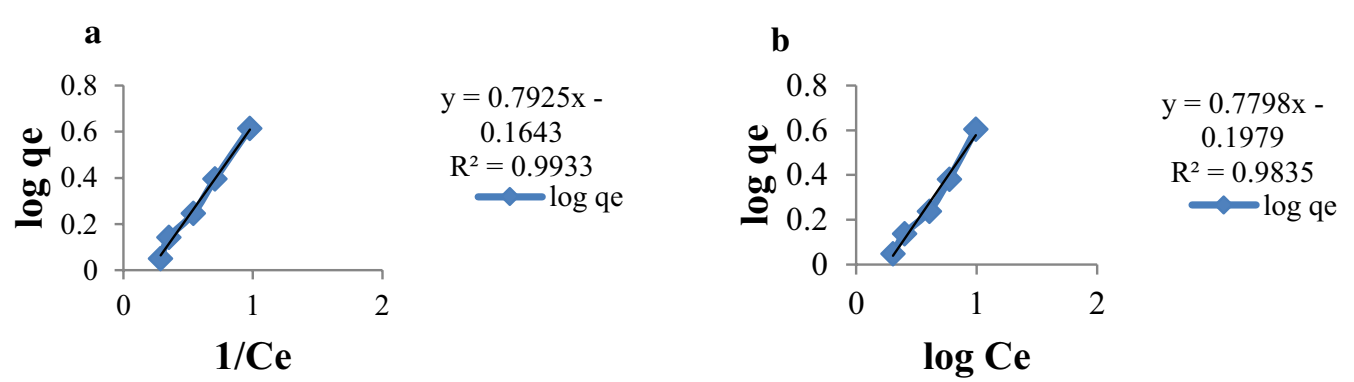

Fig. 10 Freundlich adsorption isotherms for: $\mathbf{a}$ chromium by MSSP and $\mathbf{b}$ chromium by BPP

Table 2 Pseudo-first and second order constants for chromium by MSSP and BPP

\begin{tabular}{|c|c|c|c|c|c|c|c|}
\hline \multirow[t]{2}{*}{ Metal ion } & \multirow[t]{2}{*}{$q_{\exp }$} & \multicolumn{3}{|c|}{ Pseudo first order kinetic model } & \multicolumn{3}{|c|}{ Pseudo second order kinetic model } \\
\hline & & $q_{c a l}(m g / g)$ & $k_{1}\left(\min ^{-1}\right)$ & $\mathrm{R}^{2}$ & $\mathrm{q}_{\mathrm{cal}}(\mathrm{mg} / \mathrm{g})$ & $\mathrm{k}_{2}$ (g/mgmin) & $\mathrm{R}^{2}$ \\
\hline Cr-MSSP & 1.308 & 1.449 & 0.0484 & 0.939 & 1.477 & 0.051 & 0.998 \\
\hline Cr-BPP & 1.4645 & 0.7870 & 0.023 & 0.897 & 1.631 & 0.038 & 0.994 \\
\hline
\end{tabular}

a

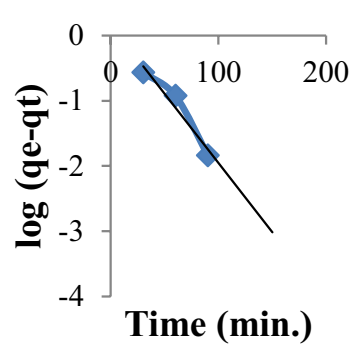

$\mathbf{b}$

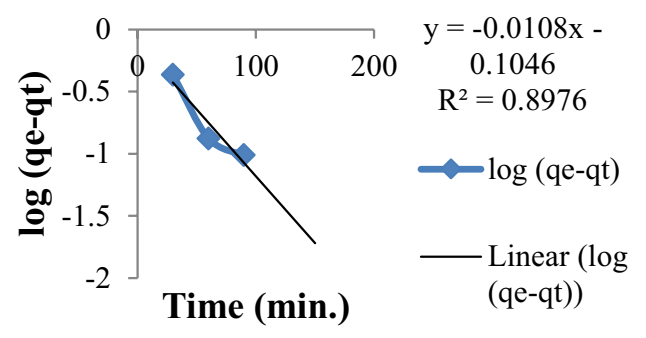

Fig. 11 Pseudo-first order kinetics plot for a chromium by MSSP and $\mathbf{b}$ chromium by BPP 
$\mathbf{a}$

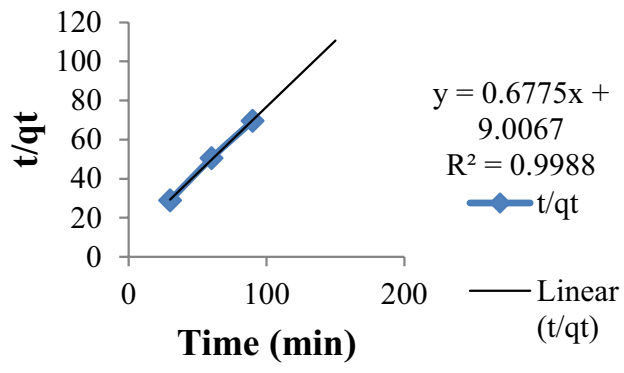

b

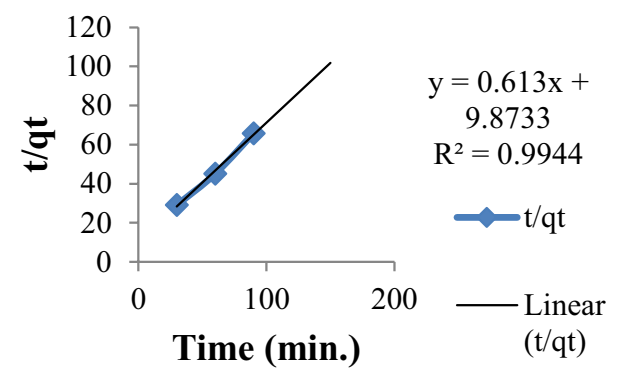

Fig. 12 Pseudo-second order kinetics plot for a chromium by MSSP and $\mathbf{b}$ chromium by BPP

Table 3 Thermodynamicparameters for $\mathrm{Cr}(\mathrm{VI})$ ion adsorptionon to MSSP and BPP atdifferent temperatures

\begin{tabular}{|c|c|c|c|c|c|c|c|c|}
\hline \multirow[t]{2}{*}{$\mathrm{T}(\mathrm{K})$} & \multicolumn{4}{|c|}{ Cr-MSSP } & \multicolumn{4}{|c|}{ Cr-BPP } \\
\hline & $\mathrm{K}^{\circ}$ & $\Delta \mathrm{G}^{\circ}(\mathrm{kJ} / \mathrm{mol})$ & $\Delta \mathrm{H}^{\circ}(\mathrm{kJ} / \mathrm{mol})$ & $\begin{array}{l}\Delta \mathrm{S}^{\circ} \\
\left(\mathrm{kJ} \mathrm{mol}^{-1}\right)\end{array}$ & $\mathrm{K}_{\mathrm{c}}$ & $\Delta \mathrm{G}^{\circ}(\mathrm{kJ} / \mathrm{mol})$ & $\Delta \mathrm{H}^{\circ}(\mathrm{kJ} / \mathrm{mol})$ & $\begin{array}{l}\Delta \mathrm{S}^{\circ} \\
\left(\mathrm{kJ} \mathrm{mol}^{-1}\right)\end{array}$ \\
\hline 293 & 1.88 & -1.535 & 39.28 & 0.129 & 2.21 & -1.924 & 42.56 & 0.140 \\
\hline 313 & 4.02 & -3.617 & & & 5.57 & -4.476 & & \\
\hline 333 & 26.05 & -9.026 & & & 28.45 & -9.275 & & \\
\hline 353 & 32.67 & -10.243 & & & 38.94 & -10.742 & & \\
\hline
\end{tabular}

model to the kinetics of adsorption onto the adsorbents it is indicated in Figs. 11 and 12.

\section{Thermodynamics study}

The values of the thermodynamic parameters for adsorption of $\mathrm{Cr}(\mathrm{VI})$ ion onto MSSP and BPP are shown in Table 3 . The increase in temperature made the values of $\Delta G^{\circ}$ more positive. A negative value of Gibbs free energy change $\left(\Delta G^{\circ}\right)$ confirms the feasibility of the process and spontaneous nature of the sorption of $\mathrm{Cr}$ (VI) ion onto MSSP and BPP. The change in Gibbs free energy decreases with increasing temperature which indicates that a lower temperature favours adsorption.

The adsorption process involves energy changes that could result in a positive or negative value of $\Delta \mathrm{H}^{\circ}$. The negative values of $\Delta \mathrm{H}^{\circ}$ in this study indicates adsorption of $\mathrm{Cr}(\mathrm{VI})$ ion onto MSSP and BPP is exothermic in nature. If enthalpy change, $\left(\Delta \mathrm{H}^{\circ}\right)$ of an adsorbent is higher than $40 \mathrm{~kJ} \mathrm{~mol}^{-1}$, the process is said to be chemisorption which includes strong electrostatic chemical bonding between the metal ions and adsorbent surface. On the other hand, enthalpy change less than $20 \mathrm{~kJ} \mathrm{~mol}^{-1}$ indicate the physical nature of the adsorption process. In this study, all the values of $\Delta \mathrm{H}^{\circ}$ are greater than $40 \mathrm{~kJ}$ $\mathrm{mol}^{-1}$ revealing that chemisorption was responsible for the adsorption $\mathrm{Cr}(\mathrm{VI})$ ion onto MSSP and BPP. The positive values of entropy, $\left(\Delta S^{\circ}\right)$, indicate the increase in randomness of sorption processes of $\mathrm{Cr}(\mathrm{VI})$ ion at the solid-liquid interface of MSSP and BPP.

\section{Conclusions}

From the current study, it can be concluded that the seed powders of Moringa stenopetala and banana peels can be used to remove $\mathrm{Cr}(\mathrm{VI})$ ion from wastewater. FT-IR characterization of the adsorbents showed that there was a change in the functional groups on the structure of both adsorbents before and after the adsorption processes. Percentage removal of $\mathrm{Cr}(\mathrm{VI})$ ion increases with decreasing $\mathrm{pH}$, increasing adsorbent dose and contact time. Adsorption isotherm were described using the Langmuir and Freundlich models. The Freundlich model fits better to the adsorption data. The kinetics study reveals that the sorption of $\mathrm{Cr}(\mathrm{VI})$ ions are faster in the pseudo-second order kinetics than pseudo first order kinetics. Thermodynamic study was investigated using $\Delta \mathrm{G}^{\circ}, \Delta \mathrm{H}^{\circ}$ and $\Delta \mathrm{S}^{\circ}$ and the negative values of $\Delta \mathrm{G}^{\circ}$ shows the spontaneous nature of the sorption process and the positive value $s$ of $\Delta \mathrm{S}^{\circ}$ indicates the randomness of the adsorption processes. The use of the greener bio-sorption process using MSSP and BPP adsorbents is important for the removal of $\mathrm{Cr}(\mathrm{VI})$ ions from wastewater in order yo safe the environment. When comparing the two adsorbents, the removal efficiency of MSSP is better than BPP. 


\section{Abbreviations}

MSSP: Moringa stenopetala seed powder; BPP: Banana peel powder; FT-IR: Fourier transformer infrared; $\Delta G^{\circ}$ : Gibbs free energy; $\Delta H^{\circ}$ : Enthalpy change; $\Delta S^{\circ}$ : Entropy change; K: Equilibrium constant; $\mathrm{k}$ : Rate constant; $\mathrm{q}_{\mathrm{e}}$ : The amount of ions adsorbed ( $\mathrm{mg} / \mathrm{g}) ; \mathrm{Q}_{\mathrm{m}}$ : The amount of ion adsorbed on monolayer $(\mathrm{mg} / \mathrm{g})$; $\mathrm{C}_{0}$ : Initial concentration of the ion $(\mathrm{mg} / \mathrm{L}) ; \mathrm{C}_{\mathrm{e}}$ : Concentration of ion at equilibrium (mg/L); R: Universal gas constant $\left(8.314 \mathrm{JK}^{-1} \mathrm{~mol}^{-1}\right)$.

\section{Acknowledgements}

The authors would like to thank Arba Minch University Department of Chemistry for allowing us to use the laboratory facilities and resources during this research work.

\section{Authors' contributions}

TSB, AMY served as writer and editor of this manuscript and supervisor of the project. EW served as producing the laboratory data and writing the manuscript. All authors read and approved the final manuscript.

\section{Funding}

This project has no any funding source.

\section{Availability of data and materials}

The authors declare that the manuscript contains the minimal dataset that is required to interpret, replicate, and build upon the methods and findings reported in the article. Raw data can be shared via correspondence upon reasonable request.

\section{Ethics approval and consent to participate}

Not applicable.

\section{Consent for publication}

Not applicable.

\section{Competing interests}

The authors declare that they have no competing interests.

Received: 2 September 2020 Accepted: 27 November 2020

Published online: 10 December 2020

\section{References}

1. Hertel RF (1986) Sources of exposure and biological effects of chromium. IARC Sci Publ 71:63-77

2. US Environmental Protection Agency (1984) Health effects assessment for hexavalent chromium. Prepared by the Office of Health and Environmental Assessment, Environmental Criteria, EPA/540/1-86-019, updated 1998

3. Anderson RA (1981) Nutritional role of chromium. Sci Total Environ 17:13-29

4. OSHA (2006) Fact sheet health effects of hexavalent chromium hexavalent. OSHA, Washington, DC

5. Saha R, Nandi R, Saha B (2011) Sources and toxicity of hexavalent chromium. J Coord Chem 64:1782-1806

6. Megharaj M, Avudainayagam S, Naidu R (2003) Toxicity of hexavalent chromium and its reduction by bacteria isolated from soil contaminated with tannery waste. Curr Microbiol 47:51-54

7. Kleber RJ, Helz GR (1992) Indirect photoreduction of aqueous chromium(VI). Environ Sci Technol 26:307-312

8. Inamuddin, Yahya A, Ismail (2010) Synthesis and characterization of electrically conducting poly-o-methoxyaniline $\mathrm{Zr}(1 \mathrm{~V})$ molybdate $\mathrm{Cd}(\mathrm{II})$ selective composite cation-exchanger. Desal 250:523-529

9. Mohammad A, Inamuddin, Hussain S (2014) Poly (3,4-ethylenedioxythiophene): polystyrene sulfonate (PEDOT:PSS) Zr(IV) phosphate composite cation exchanger: sol-gel synthesis and physicochemical characterization. Ionics 21:1063-1071
10. Shokrollahi M, Rezakazemi M, Younas M (2020) Producing water from saline streams using membrane distillation: modeling and optimization using CFD and design expert. Int J Energy Res. 44(11):8841-8853

11. Shokrollahi M et al (2019) Application of $\mathrm{ZnO}$ nanostructures in ceramic and polymeric membranes for water and wastewater technologies. Chem Eng J 391:123475

12. Marzieh $\mathrm{S}$ et al (2019) Zeolitic imidazolate framework membranes for gas and water purification. Environ Chem Lett 18:1-52

13. Badessa T, ShaposhnikV (2016) The electrodialysis of electrolyte solutions of multi-charged cations. J Membr Sci 498:86-93

14. Holan ZR, Volesky B (1995) Biosorption of heavy metals. Rev Biotechnol Progr 11:235-250

15. Ahluwalia SS, Goyal D (2007) Microbial and plant derived biomass for removal of heavy metals from wastewater. Bioresour Technol 98:2243-2257

16. Sobhanardakani S, Parvizimosaed H, Olyaie E (2013) Heavy metals removal from wastewaters using organic solid waste rice husk. Environ Sci Pollut Res 20:5265-5271

17. Jahn SAA (1991) The traditional domestication of a multipurpose tree Moringa stenopetala (Bak. F.) Cuf. in the Ethiopian Rift Valley. Ambio 20:244-247

18. ICRAF (2006) Moringa stenopetala. http://www.Worldagroforestry.org/ Sea/Products/AFDbases/AF/asp/Species/nfo.asp. Accessed 8 Sept 2006

19. Demeulenaere E (2001) Moringa stenopetala, a subsistence resource in the Konso district. In: Proceedings of the international workshop development potential for Moringa products, October 29-November 2, 2001, Dar-Es-Salaam, Tanzania. p 2-29

20. Abuye C, Urga K, Knapp H, Selmar D, Omwega AM, Imungi JK (2003) A compositional study of Moringa stenopetala leaves. East Afr Med 80:247-252

21. Jose TA, Silverio BS, Vasconcelos LM, Cavada BS, Moriera RA (1999) Compositional and nutritional attributes of seeds from the multipurpose tree Moringa oleifera Lam. J Sci Food Agric 79:815-820

22. Food and Agriculture Organization Statistical Database (2016) http:// faostat3.fao.org/download/T/*/E. Accessed 23 June 2016

23. Food and Agriculture Organization Statistical Database (2012) "Overview of world banana production and trade". The world banana economy, 1985-2012. Food and Agriculture Organization of the United Nations Corporate Document Repository. Produced by Economic and Social Development Department, Rome, Italy. http://faostat3.fao.org/home/ index.html. Accessed 1 June 2016

24. Beed F, Duboic T, Markham R (2012) A strategy for banana research and development in Africa. A synthesis of results from the conference banana 2008, held in October 2008, Mombasa, Kenya. International Society for Horticultural Science, Leuven

25. Foo KY, Hameed BH (2010) Insights into the modeling of adsorption isotherm systems. Chem Eng J 156:2-10

26. Mohapatra D, Mishra S, Sutar N (2010) Banana and its by-product utilisation: an overview. J Sci Ind Res 69:323-329

27. APHA (1998) APHA method 3500-Cr (D)-colorimetric method: standard methods for the examination of water and wastewater, 20th edn.

28. American Society for Testing and Materials (1991) Standard method for moisture in activated carbon ASTM D 2867-91. ASTM Committee on Standards, Philadelphia

29. Dawodu FA, Akpomie KG (2014) Simultaneous adsorption of $\mathrm{Ni}(\mathrm{II})$ and $\mathrm{Mn}(\mathrm{II})$ ions from aqueous solution onto a Nigeria kaolinite clay. J Mater Res Technol 3:129-141

30. Deng H, Yang L, Tao G, Dai J (2009) Preparation and characterization of activated carbon from cotton stalk by microwave assisted chemical activation. Application in mathylene blue adsorption from aqueous solution. J Hazard Mater 166:1514-1521

31. Mahmood T et al (2011) Comparison of different methods for the point of zero charge determination of NiO. Ind Eng Chem Res 50:10017

32. Lagergren $S(1898)$ Zurtheorie der sogenannten adsorption gelosterstoffe. Kungliga Svenska Vetenskapsakademiens Handlingar 24:1-39

33. Ho YS, McKay G, Wase D, Foster CF (2000) Study of the sorption of divalent metal ions on to peat. Adsorpt Sci Technol 18:639-650

34. Langmuir I (1916) The constitution and fundamental properties of solids and liquids. J Am Chem Soc 38:2221-2295 
35. Thamilarasu P, Sivakumar P, Karanakaran K (2011) Removal of Ni(II) from aqueous solution by adsorption onto Cajanus cajan L. Milsp seed shell of activated carbon. J Chem Technol 18:414-420

36. Thilagavathy P, Santhi T (2013) Sorption of toxic Cr(III) from aqueous solutions by using treated Acacia nilotica leaf as adsorbent: single and binary system. J Bioresour 8:1813-1830

37. Kumar M, Tamilarasan R (2013) Modeling of experimental data for the adsorption of methyl orange from aqueous solution using a low cost activated carbon prepared from Prosopis juliflora. J Chem Technol 15:29-39

38. Freundlich HMF (1906) Over the adsorption in solution. J Phys Chem 57:385-470

39. Meena AK et al (2005) Removal of heavy metal ions from aqueous solutions using carbon aerogel as an adsorbent. J Hazard Mater 122:161-170

40. Rao PS et al (1992) Kinetic studies on adsorption of chromium by coconut shell carbons from synthetic effluents. J Environ Sci Health 27:2227-2241

41. Attia AA, Khedr SA, Elkholy SA (2010) Adsorption of chromium ion (VI) by acid activated carbon. Braz J Chem Eng 27:183-193

42. Bhutada PR et al (2016) Solvent assisted extraction of oil from Moringa oleifera Lam. seeds. Ind Crops Prod 82:74-80

43. Araújo CST et al (2010) Characterization and use of Moringa oleifera seeds as biosorbent for removing metal ions from aqueous effluents. Water Sci Technol 62:2198-2203
44. Bhatti I, Qureshi K, Kazi RA, Ansari AK (2007) Preparation and characterization of chemically activated almond shells by optimization of adsorption parameters for removal of chromium(VI) from aqueous solutions. Int J Chem Mol Eng 1(10):105-110

45. Hammaini A et al (2007) Biosorption of heavy metals by activated sludge and their desorption characteristics. J Environ Manag 84(4):419-426

46. Özbay N, Yargiç RZ, Yarbay S, Önal E (2013) Full factorial experimental design analysis of reactive dye removal by carbon adsorption. J Chem $113: 4$

47. Timbo CC, Kandawa-Schulz M, Kwaambwa HM (2017) Adsorptive removal from aqueous solution of $\mathrm{Cr}(\mathrm{VI})$ by green moringa tea leaves biomass. J Encapsul Adsorpt Sci 7:108-119

48. Donmez D, Aksu Z (2002) Removal of chromium(VI) from saline wastewaters by Dunaliella species. Process Biochem 38:751-762

\section{Publisher's Note}

Springer Nature remains neutral with regard to jurisdictional claims in published maps and institutional affiliations.
Ready to submit your research? Choose BMC and benefit from:

- fast, convenient online submission

- thorough peer review by experienced researchers in your field

- rapid publication on acceptance

- support for research data, including large and complex data types

- gold Open Access which fosters wider collaboration and increased citations

- maximum visibility for your research: over $100 \mathrm{M}$ website views per year

At BMC, research is always in progress.

Learn more biomedcentral.com/submissions 